\title{
Maaltye as seremonies in die Markusevangelie: 'n Sleutel om J H J A Greyvenstein en A S Geyser se denke oor die Nederduitsch Hervormde Kerk van Afrika as volkskerk te evalueer
}

\author{
Ernest van Eck \\ Universiteit van Pretoria
}

Tydelik-deeltydse dosent: Departement Nuwe-Testamentiese Wetenskap (Afd A)

\begin{abstract}
Meals as ceremonies in Mark's gospel: A key to evaluate the understanding of the Nederduitsch Hervormde Kerk van Afrika as 'peoples church' by J H J A Greyvenstein and A S Geyser

This article aims to participate in the current debate regarding the writing of a new church order for the Nederduitsch Hervormde Kerk van Afrika, concentrating on Article III of the current church order. In a previous article the understanding of the Nederduitsch Hervormde Kerk as a 'peoples church' ('volkskerk') by Professors J H J A Greyvenstein and A S Geyser - both New Testament scholars in teaching positions at the University of Pretoria between 1917 and 1961 - was traced. This understanding is now critically evaluated by means of a social-scientific analysis of meals as ceremonies in Mark's gospel. The conclusion reached is that Mark proclaimed - as Greyvenstein and Geyser advocated - the presence and availibility of God as aspects that should ecclesiologically be open to all. Finally, a few remarks are made concerning the continuation of the debate on the new church order for the Nederduitsch Hervomde Kerk van Afrika.
\end{abstract}

\section{INLEIDING}

Die term 'volkskerk' en die Nederduitsch Hervormde Kerk van Afrika se Artikel III as uitdrukking van die kerk se selfverstaan as volkskerk, het te make met grense, of anders gestel: die ekklesiologiese insluit en uitsluit van bepaalde persone (Pont

* Hierdie artikel is die tweede deel (kyk van Eck 1995:825-850) van 'n geredigeerde weergawe van 'n referaat gelewer op 26 Mei 1994 tydens 'n Nuwe-Testamentiese gespreksgroep-byeenkoms onder leiding van prof dr G M M Pelser, Fakulteit Teologie (Afd A), Universiteit van Pretoria. 
1994a:5; 1994b:5; Van Eck 1994b:4, 8; Van Staden 1994a:713-729; 1994b:10411069; Van Wyk 1994:755-779; Van der Westhuizen 1995:8). Selfs wanneer die begrip 'volkskerk' gevul word met 'n positiewe inhoud, te wete as aanduiding van die gerigtheid van die kerk tot die normale en vanselfsprekende organiese verbande waarin mense lewe (soos die gesin en volk; kyk Van der Westhuizen 1990:71; Van Wyk 1991:777; Van Zyl 1989:86-98; Dreyer 1995:5), dui dit op 'n bepaalde afgrensing ten opsigte van sekere persone.

In die Nuwe-Testamentiese wetenskap word die kruis-kulturele teorie rakende seremonies as sosiaal-wetenskaplike model ingespan om onder andere die dinamiek agter en betekenis van etes/maaltye in ander kulture as die eie te ondersoek. Soos hieronder aangetoon sal word, het maaltye, as seremonies, in die eerste-eeuse Mediterreense wêreld gedien as 'n konstante herdefiniëring van die eie van 'n bepaalde groep, dit wil sê, die trek van grense. Soos Artikel III as 'n simbool van insluiting en/of uitsluiting ten opsigte van kerkbywoning en kerklidmaatskap funksioneer, so was dit met maaltye in die eerste-eeuse Mediterreense wêreld - dit het die samelewing georden in terme van ' $n$ bepaalde verstaan van God, die eie, en die self.

Wat was Jesus se houding ten opsigte van hierdie simbool van ordening en insluiting/uitsluiting van sy tyd? Die res van hierdie artikel is 'n poging om hierdie vraag te antwoord.

\section{ETES AS SEREMONIES IN DIE EERSTE-EEUSE MEDITERREENSE WÊRELD}

Die begrip kultuur kan onder andere verstaan word as 'the whole arrayof interlocking symbols and sets of symbol systems in any society' (Turner 1967:12; 1969:96). Kultuur is dus ' $n$ sisteem van simbole - 'n sisteem waardeur die samelewing georden en in stand gehou word. As seremonie is maaltye in die eerste-eeuse Mediterreense wêreld ' $n$ simbool waardeur die samelewing georden is. '[It] served the purpose of ordering, that is drawing and redrawing boundaries around the both natural and social spaces and identify them as good or bad, inside or outside, clean or unclean, high or low' (McVann 1991a:334). Seremonies dus, as boustene van 'n bepaalde samelewing of kultuur, skep en hou so 'n samelewing in stand (kyk Turner 1969:99; Sahlins 1976:78; McVann 1988:97; 1991a:334).

'n Maklike manier om seremonies as simbool in die eerste-eeuse-Mediterreense wêreld te definieer, is om dit te vergelyk met 'n ander simbool in dieselfde samelewing, te wete die ritueel (vir 'n beskrywing van rituele, kyk o a Turner 1967, 1969; Malina 1986:139-142; McVann 1988:96-101; 1991a:334-335; 1991b:151-157; Van Eck 1993:196-198). Seremonies (soos etes/maaltye) en rituele (soos die ontvangs van die doop of om genees te word) kan van mekaar onderskei word by wyse van die volgende kenmerke: 
As onderbreking van die normale, daaglikse roetine van mense, vind seremonies gereeld plaas, en wanneer dit ongereeld plaasvind, staan dit bekend as ' $n$ ritueel. Seremonies is dus voorspelbaar en word gewoonlik beplan. Daarteenoor is die ritueel onvoorspelbaar en vind slegs plaas wanneer dit nodig is. Verder is verskillende persone in beheer van seremonies en rituele: diegene wat in beheer van seremonies is, word 'officials' (bv die vader/moeder by die etenstafel of die priester wat 'n offer namens iemand bring) genoem, en diegene wat in beheer is van rituele staan beken as 'professionals' (bv dokters of regters).

Soos hierbo genoem, funksioneer seremonies in terme van die herbevestiging van waardes en strukture wat betref die sosiale instellings van die betrokke samelewing. Sosiale instellings is gebaseer op bepaalde vaste ooreenkomste, regte en verpligtinge (wat bekend staan as rolle), op verhoudinge tussen bepaalde rolle (genoem statusse), en op opeenvolgende statusse wat in die betrokke samelewing aan die werk is en deur almal erken word (kyk Van Staden 1991:194). Voorbeelde van sosiale instellinge is kultuur, opvoeding, poiitiek, ekonomie en godsdiens. Seremonies bevestig en herbevestig dus die sosiale instellings wat die samelewing struktureer. Verder bevestig dit telkens die statusse van persone in hierdie instellings, en demonstreer die solidariteit tussen diegene wat aan die betrokke instellings vorm gee. Rituele, aan die ander kant, funksioneer in terme van die verandering van status. Persone wat byvoorbeeld uitgesluit was uit die samelewing, omdat hulle as onrein gereken is, kan deur ' $n$ priester as rein verklaar word, en só van status verander. Seremonies fokus dus op 'n tydspan verlede-tot-hede (soos sake in die verlede was, word dit nou weer herbevestig), en rituele fokus op 'n tydspan hede-tot-toekoms (hoe sake nou is, anders sal wees in die toekoms).

Uit bogenoemde definisie van seremonies is dit duidelik dat die eet van voedsel/tafelgemeenskap as seremonie in die eerste eeuse-Mediterreense wêreld gesien is. Die eerste eeuse-Mediterreense wêreld ( $\mathrm{d}$ w s, die wêreld van Jesus), het verder die samelewing gestruktureer deur die klassifikasie van persone, plekke, dinge en tye. So is orde 'geskep' in ' $n$ andersins 'chaotiese' samelewing (Neyrey 1991c:271-304). Sodanige klassifikasie was die uitdrukking van 'n bepaalde groep se verstaan van hulle simboliese universum, van God, die self en die eie. Volgens Neyrey (1991b:365) is laasgenoemde veral waar as dit kom by klassifisering van persone, plekke, dinge en tye rondom maaltye omdat, soos Cohen (1968:508) tereg opgemerk het, '[i]n no society are people permitted to eat everything (dinge - EvE), everywhere (plekke - EvE), with everyone (persone - EvE), and in all situations (tyd - EvE; kyk ook Crossan 1991:341; Elliott 1991b:386-399). 
Ook Feeley-Harnik (1981:10) is van mening dat etes gesien kan word as 'n simbool van groepsidentifikasie:

[I]t is owing precisely to the complex interrelationships of cultural categories that food is commonly one of the principal ways in which differences among social groups are marked.

Klosinski (1988:56-58) huldig dieselfde mening:

[S] haring food is a transaction which involve a series of mutual obligations and which initiates an interconnected complex of mutuality and reciprocity. Also, the ability of food to symbolize these relationships, as well as to define group boundaries, surfaced as one of the unique properties of human interaction .... Eating is a behavior which symbolizes feelings and relationships, mediates social status and power, and express the boundaries of group identity.

Die 'map of persons' ' (kyk o a Neyrey 1991c:279; Van Eck 1993:215; Van Staden 1994b:1058), soos geïmplimenteer deur die Fariseërs (die Markaanse Jesus se teenstanders op Galilese bodem; vgl Mark 7:1, kyk ook Mark 2:18; 8:11, 15), illustreer duidelik die beginsel dat persone net saam met ander eet wat dieselfde waardes en oortuigings as hulle deel. Juis daarom kan die Fariseërs nie verstaan hoekom Jesus, as sogenaamde 'man van God', saam met sondaars en tollenaars kan eet nie (vgl Mark 2:13-17). So het die Jood ook, in die algemeen, nie saam met heidene geëet nie.

Selfs wanneer 'soort' saam met 'soort' geëet het (d w s, Fariseër saam met Fariseër), was daar 'n 'map of persons' aan tafel teenwoordig. Status en rol in terme van die groep het die posisie en sitplek aan tafel bepaal, en alle deelnemers aan die ete het ook nie dieselfde, en dieselfde hoeveelheid, kos ontvang om te eet nie (Pervo 1985:311-313).

Voedsel is, in terme van die 'map of things' (Neusner 1979:109), geklassifiseer as rein of onrein. Sommige voedsel (bv diere met 'n gebrek) was outomaties onrein (kyk Lev 11:1-47; cf Douglas 1966:41-57; 1972), ander weer moes op spesifieke wyses voorberei word, terwyl sommige voedsel rein verklaar is by wyse van tiendes wat daarop betaal is. Ook die houers/potte waarin voedsel voorberei is, het bepaal of sekere kosse rein of onrein was (vgl Mark 7:4). Selfs sekere gesprekke aan tafel was gepas of onvanpas (vgl Neyrey 1991b:365-366; Feuilett 1965:76-101). 
In terme van die 'map of places' (kyk m. Kelim I, 6-9, in Danby 1933:605-606), was dit byvoorbeeld vir die Farisëer belangrik waar geëet is. Die rede hiervoor was die feit dat die plek waar geëet is, bepalend was vir die regte voorbereiding van voedsel, nie alleen met die oog op dit waarin die voedsel voorberei is nie, maar ook waarop dit bedien is (Neyrey 1991b:366). Laastens, in terme van die 'map of times', moes sekere voedsel op sekere tye geëet word (Danby 1933:i), byvoorbeeld net sekere voedsel tydens sekere feeste. In sommige gevalle is voedsel ook in 'n sekere volgorde geëet, anders sou so 'n maaltyd onrein wees (vgl Jeremias 1968:41-62; Bahr 1970:182; Douglas 1972:66).

Uit bogenoemde is dit duidelik dat die maatreëls en norme rakende voedsel en maaltye in die eerste-eeuse Mediterreense wêreld verstaan kan word as 'n replisering van bepaalde sosiale kategorieë en sosiale groeperinge asook die reëls van die sosiale sisteem waarin maaltye plaasvind (vgl Douglas 1966:41-57; kyk ook Leach 1969:5561; Feeley-Harnik 1981:6-18; Douglas 1982:1-39; Harris 1985:61-68). Of, om dit eenvoudig te stel: maatreëls (kodes) by die tafel repliseer die kodes van die samelewing. Elliott (1991b) en Douglas (1972) formuleer hierdie verband tussen maaltye (as seremonies) en die sosiale kodes wat dit repliseer, soos volg:

In any society or sub-group thereof, there is generally a correlation of the rules and boundaries concerning what one eats, with whom one eats, when one eats, how one eats, where one eats, to what community, group, or kinship network one belongs, and what constitutes the group's traditions, values, norms, and worldview.

(Elliott 1991a:103; my beklemtoning)

If food is treated as a code, the message it encodes will be found in the pattern of social relations being expressed. The message is about different degrees of hierarchy, inclusion and exclusion, boundaries and transactions across the boundaries. Like sex, the taking of food has a social component, as well as a biological one. Food categories therefore encode social events ... the ordered system which is a meal represents all the ordered systems associated with it.

(Douglas 1972:61) 
Maaltye was dus 'n kragtige (eksklusiwistiese) simbool in die wêreld van Jesus, in die sin dat veral die wyse, wat en saam met wie geëet is, 'n uitdrukking was van wie rein/onrein, 'sondaar'/'sonder sonde' was, maar veral wie behoort het tot die in-groep en die uit-groep. '[W] ho may eat what with whom is a direct expression of social, political, and religious relations' (Feeley-Harnik 1981:2).

\section{JESUS EN SEREMONIES (MAALTYE) IN MARKUS}

Jesus se houding teenoor bogenoemde verstaan van maaltye as simbool en uitsluitende beginsel van wie tot die volk van God behoort en wie nie, kom veral na vore in vier mikro-vertellinge in die Markusevangelie, te wete Markus 2:15-17 (waar Jesus saam met Levi en ander tollenaars eet), Markus 2:18-20 (waar Jesus en sy dissipels eet terwyl die Fariseërs vas) en Markus 6:35-44 en 8:1-10 (die vermeerdering van die brood en die visse).

Uit Markus 2:15-17 kan duidelik afgelei word dat Jesus hom nie gesteur het aan wie saam met wie mag geëet het nie (die sogenaamde 'map of persons'). Die tollenaars saam met wie Jesus hier eet, was beskou as mense wat in 'n permanente staat van sondaar/onrein was (kyk Van Eck 1993:210-220). Dit is juis om hierdie rede dat die Fariseërs Jesus daarvan beskuldig dat hy saam met 'tollenaars en sondaars' eet (Mark $2: 16$ ). Vir Jesus was daar dus nie 'n beperking ten opsigte van saam met wie geëet mag word nie. Waar hy geëet het, was almal welkom.

Uit Markus 2:18-20 kan verder afgelei word dat Jesus hom ook nie gesteur het aan wanneer daar sogenaamd geëet of nie geëet mag word nie. Terwyl die dissipels van Johannes en die Fariseërs vas, eet Jesus en sy dissipels. As verkondiger van die koninkryk van God (Mark 1:15), was God by Hom teenwoordig, daarom ook by almal wat saam met hom eet. En in die koninkryk van God, sê Jesus, kan almal eet wanneer hulle wil (Mark 2:15-17).

Hierdie standpunt van Jesus kan ook afgelei word uit Markus 6:35-44 en Markus 8:1-10. In beide hierdie gevalle word Jesus en die skare deur die verteller geplaas as by 'n eensame plek (Mark 6:35; 8:4). Soos bo aangetoon, was 'n eensame plek nie geskik vir 'n maaltyd nie, aangesien daar nie genoeg water (vir almal) sou wees om die voorgeskrewe reinheidsrites vooraf na te kom nie, soos die was van hande. Ook net sekere kos was beskikbaar (brood en vis), daar kon nie bepaal word of tiendes daarop wel betaal is nie, en die situasie self het hom nie daartoe geleen het dat hierdie voedsel op die regte wyse en in die regte houers voorberei kon word nie.

Tydens Jesus se maaltye is daar ook nie sekere plekke wat belangriker as ander geag is nie of wat sogenaamd meer status as ander het nie. Jesus gee aan die dissipels opdrag om al die mense in groepies op die gras te laat sit, en relativeer dus so alle 
posisies van eer of status. By sy maaltye is almal gelyk en ewe belangrik. Of anders gesê: Jesus se maaltye was nie alleen 'oop' vir almal nie, almal was ook gelyk in status. By Jesus was daar nie 'ereplekke by ... feesmaaltye' (Mark 12:39) nie, en almal het net een status gehad, naamlik om deel te wees van die koninkryk van God. Hierdie status, sê Jesus op 'n ander plek, is dié van dienskneg wees (vgl Mark 10:4244).

Uit Markus 6:35-44 en 8:1-10 is dit verder duidelik dat al die deelnemers dieselfde kos ontvang, asook dieselfde hoeveelheid, aangesien daar oor was en almal dus soveel kon eet as hulle wou. Ook is dit duidelik dat, soos afgelei kan word uit Markus 7:24 en 31, die mikro-vertelling in Markus 8:1-10 afspeel in heidense gebeid. Heidene was waarskynlik dus teenwoordig by hierdie geleentheid. Uit Markus 6:53-56 (die beskrywing van die skare waarvan Jesus sommiges genees) is dit verder afleibaar dat verskeie 'sondaars' saam met Jesus geëet het.

Laastens is dit insiggewend dat Jesus, in Markus 6:41 en 8:6, voordat hy die dissipels opdrag gee om die kos aan almal teenwoordig uit te deel (vgl weer die dienskneg-motief), bid. Die gebed van Jesus kan, myns insiens, in verband gebring word met Markus 7:18-19, waar Jesus alle voedsel rein verklaar.

Om op te som: Maaltye, as sermonies, was vir die Jood 'n simbool van uitsluiting, 'n simbool wat gedui het op wie hoort en wie nie hoort tot die volk van God nie. Vir die Markaanse Jesus was maaltye egter 'n simbool van iets anders, 'n simbool van insluiting. Jesus se maaltye was 'oop', die plek waar 'sondaars' ontmoet het om 'kinders van die koninkryk' te word. Die plek waar God nie alleen teenwoordig was nie, maar ook beskikbaar vir almal was. Enige kos is op enige plek saam met enigeen geëet. Almal was welkom. En almal wat geëet het, was gelyk in status voor God.

So verstaan, was Jesus se maaltye die skep van 'n nuwe, uitgebreide huishouding, 'n simbool van inklusiwisme, liefde, diens, gelykheid, gasvryheid, solidariteit, geen diskriminasie en vrye toegang tot God. Jesus se maaltye geld dus as simbool van God se vrye genade wat vir almal beskikbaar is en behoort te wees.

\section{KONKLUSIE}

Vir Greyvenstein is die Christendom die godsdiens van die liefde, en behoort die liefde daarom dié kenmerk van die kerk te wees. Daarteenoor is klassevoordeel en persoonlike en nasionale meerwaardigheid nie alleen die groot struikelblok in die weg van die liefde en algemene humaniteit nie, maar ook die groot struikelblok in die weg van liefdevolle kerkwees (kyk Van Eck 1995:842-844).

Geyser weer, op sy beurt, tipeer die vroeg-Christelike kerk as universeel-gerigte (inklusiewe) sendingkerk wat met stryd sy partikulier-Joods (eksklusiewe) begrensing begin ontgroei het. Eksklusiwisme in die kerk is alleen moontlik wanneer die liefde in 
die kerk alleen ' $n$ liefde met beperkings en kwalifikasies is, ' $n$ liefde-vir-die-eie en ' $n$ neutrale welwillenheid teenoor die nie-eie, solank laasgenoemde net nie sy gesigsveld betree en die uitvoering van sy ideële programme beswaar nie. Rasseskeiding is nie alleen teen die Skrif nie, maar die eenheid van die kerk is geheel in Christus objektief gefundeer. Toelating tot die kerk kan dus alleen plaasvind op grond van die Christusbelydenis, en geen ander maatreël mag in die pad van enige persoon staan om deel van die gemeenskap van die gelowiges te word, indien so 'n persoon hierdie belydenis uitspreek nie (kyk Van Eck 1995:842-844).

Vir beide Greyvenstein en Geyser is iets soos 'n eksklusiewe volkskerk dus 'n onmoontlike moontlikheid. Artikel III, soos dit ontwikkel het as simbool van uitsluiting uit die geloofsgemeenskap op grond van ras en kleur, sou dus vir hulle nooit aanvaarbaar kon wees nie. Dit is alleen liefde-vir-die-eie, eksklusief en uitsluitend.

In die geval van die Markaanse Jesus was dit dieselfde. In die samelewing, waarvan die Jood Jesus deel was, was maaltye ook simbole van uitsluiting. Maaltye was simbole van die definiëring en herdefiniëring van grense. Dit het dus bepaal en herbepaal wie 'in' en wie 'uit' was. So is nie alleen sogenaamde toegang tot God gereguleer nie, maar is mense ook uit die gemeenskap en geloofsgemeenskap geostraseer, asof God nooit by hulle teenwoordig kan wees nie.

Vir die Markaanse Jesus was maaltye ook 'n simbool, maar 'n simbool van die teenwoordigheid van God by alle mense. Daarom was Jesus se maaltye oop, almal was welkom, insluitend die 'sondaars en tollenaars' van sy tyd. Niemand is weggewys nie. Almal kon deel word van 'n gemeenskap van liefde, diens, gelykheid, gasvryheid, solidariteit, geen diskriminasie en vrye toegang tot God. As deel van die Markaanse Jesus se verkondiging van die evangelie as universeel-gerig en insluitend, was Jesus se maaltye dus universeel-gerig en insluitend - 'n sigbare eenheid in liefde rondom die teenwoordigheid van God. Vir die Markaanse Jesus sou Artikel III dus ook 'n onmoontlike moontlikheid gewees het.

\section{SLOTOPMERKINGS}

Bogenoemde negatiewe beoordeling van die Nederduitsch Hervormde Kerk van Afrika se selfverstaan as volkskerk - met Artikel III as die simboliese uitdrukking daarvan beteken egter nie dat 'n kerk nie volksgerig mag werk en bestaan nie (Küng 1971:274; Pelser 1994:323; Van Eck 1994a:4). Myns insiens het Greyvenstein, en veral Geyser, dit nooit ontken nie. Geyser (1960/1961b:7) se probleem met die volkskerkidee van die Nederduitsch Hervormde Kerk het eerder daarin geleë dat sommiges in die Hervormde Kerk die gerigtheid van die kerk ingeperk het in terme van nasionale en politieke begrensing. Die volkskerkidee het syns insiens 'n ondersteunende ideologie vir 
eksklusiwiteit geword. Vir Geyser (1961:9) het dit nie gegaan oor die organisatoriese eenheid van die kerk (of dat eredienste as dwingende beginsel gemeng moes wees nie), maar bloot dat alle gelowiges, nieteenstaande hulle onderskeid van ras en kleur, as beginsel onbelemmerd en vry aan enige kerk kon behoort en, by implikasie, eredienste kon bywoon. Dit was in elk geval duidelik dat Greyvenstein, en veral Geyser, geen probleem gehad het om, saam met hulle liefde vir hulle volk, ook die universele gerigtheid van die evangelie te kon verdedig nie (vgl bv Geyser 1953:33-34, 1960/1961 a:2730; Greyvenstein 1920:vi-vii; 1938:4-5). Nademaal kan (en sal) die Hervormde Kerk dus 'volkskerk' wees, maar sodra gerigtheid tot die volk - en slegs toelating van die volk tot die kerk - 'n wesenskenmerk van die kerk word, is die kerk nie meer kerk van Christus nie.

'n Laaste woord: Dit is waar dat veral Geyser se persoonlikheid, en sekere ongevraagde (en geniepsige) kritiek teenoor die kerk, somtyds groot ongelukkigheid in die kerk veroorsaak het (kyk bv Heyneke 1963:24, Naude 1960:18; Pont 1990:9-11; Geyser 1960:18). Juis daarom is die oproep van die huidige redakteur van Die Hervormer (kyk Van Wyk 1994a:4; 1994b:4) nie ongevraagd wanneer ons in die toekoms oor Artikel III en verwante sake in die kerk (soos die sendingbeleid, multikulturêle bediening(e) en ekumeniese verhoudinge) sal debateer nie.

Die volgende opmerking van Oberholzer (1993:880), wanneer hy skryf oor die teologiese strominge en teologiese debat in die Hervormde Kerk in die vroeë sestigs, moet daarom ook hier vermeld word:

Die geleentheid [in die verlede] was daar om duideliker en intenser as ooit tevore te teologiseer, maar dit is 'n ope vraag of die Hervormde Kerk en sy teoloë ryp genoeg was om die geleentheid te benut.

(Oberholzer 1993:880)

In dieselfde bydrae stel Oberholzer (1993:874) dit ook duidelik wat die grond vir die toekomstige debat behoort te wees:- 'Die eg Hervormde erfenis bly steeds die sola Scriptura'. Wat betref die toekomstige debat oor die skryf van die nuwe kerkwet, kan ons wat daaraan gaan deelneem, ook die volgende opmerking van Schillebeeckx ter harte neem:

Moreover we note that the fall and rise of the whole history of the church consists in a new discipleship of Jesus or walking in Jesus' footsteps, and in a constant ongoing process of interpretation in which 
Christians, constantly confronted afresh with other situations and problems in the church and in the world, in faithfulness to the tradition handed down, accept in faith and yet critically weigh what previous generations passed on.

(Schillebeeckx 1987:35-36).

Dit is waartoe die kerk in elke nuwe situasie bereid sal moet wees: om die Skrif alleen weer en weer te laat spreek, terwyl die kerk krities aan die verlede en tradisie vashou. Anders gee die kerk aan die tradisie van die vadere dieselfde geldigheid as dié wat die Woord toekom (Geyser 1960/1961b:304). Die kerk het net een bestaansrede - om op alle plekke onder alle omstandighede aan alle mense te getuig dat Jesus die Christus en die openbaring van Gods liefde aan almal is. As die kerk nie daaraan (wil) voldoen nie, kom die kerk as kerk van Christus in gedrang.

\section{Endnota}

1 Volgens Jeremias (1969:271-272) kom die lys van die klassifikasie van persone in die eerste eeuse-Mediterreense wêreld in verskeie rabbynse literatuur voor (kyk Kid $4.1 ; \mathrm{m}$. Hor 3.8; $\mathrm{t}$. Rosh Has 4.1). Die mees volledige lys kom voor in t. Megillah 4.7 (kyk Danby 1933:403).

\section{Literatuurverwysings}

Bahr, G J 1970. The ceder of Passover and the eucharistic words. NT 12, 181-202. Botha, S J (red) 1989. Belydende volkskerk. Pretoria: Kital.

Cohen, Y A 1968. 'Food: II. Consumption patterns, in Sills, D (ed), International encyclopedia of the social sciences, Vol 5, 508-513. New York: MacMillan/Free Press.

Crossan, J D 1991. The historical Jesus: The life of a Mediterranean Jewish peasant. New York: Harper San Francisco.

Danby, H 1933. The Mishnah. Oxford: The Clarendon Press.

Douglas, M T 1966. Purity and danger: An analysis of the concepts of pollution and taboo. London: Routledge \& Kegan Paul.

- 1972. 'Deciphering a meal'. Daedalus 101, 61-81.

1982. In the active voice. London: Routledge \& Kegan Paul.

Dreyer, W A 1995. Hier staan ek ... Frans van Zyl. Die Hervormer, 15 April 1995, bl 5 en 8.

Elliott, J H 1991a. Household meals vs. temple purity. BTB 21/3, 102-108.

1991b. Household and meals versus the temple purity system: Patterns of replications in Luke-Acts. HTS 47/2, 386-399. 
Feeley-Harnik, G 1981. The lord's table: Eucharist and Passover in early Christianity. Philadelphia: University of Pennsylvania Press.

Feuilett, A 1965. Johannine studies. Staten Island: Alba House.

Geyser, A S 1953. Wyle prof H G Viljoen. HTS 9/3 \& 4, 82-93.

- 1960. Die eerste evangelie oor die eenheid van die kerk as Christusgetuienis, in Geyser, Marais, Du Plessis, Keet \& Van Selms 1960:12-23.

1960/1961a. Christelike godsdiens en eiesoortige volksdiens: 'n Beoordeling van die boek van prof dr A B du Preez, Eiesoortige ontwikkeling tot volksdiens. HAUM, Pretoria , 1959. HTS 16, 1-30

— 1960/1961b. Logos en ideologia: Woord en skynwoord. HTS 16, 300-307.

— 1961. Die Skrif beveel 'n sigbare eenheid van die kerk. Die Hervormer, Maart 1961, bl 5, 9, 16.

Geyser, A S, Marais, B J, Du Plessis, H, Keet, B B, Van Selms, A et al 1960. Vertraagde aksie: 'n Ekumeniese getuienis uit die Afrikaanssprekende kerk. Pretoria: NG Kerkboekhandel.

Greyvenstein, J H J A 1920. In memoriam: Ds Goddefroy. De Hervormer, 15 September 1920, bl vi-vii. (Jr $12 \mathrm{nr} 3$.)

1938. Eeufees-oordenking: 'Ek dink aan die dade van die Here; Ja ek wil dink aan U wonders uit die voortyd' (Ps 77 vs 12). De Hervormer 30 November 1938, bl 4-5. (Jr $29 \mathrm{nr} 15$.

Harris, M A 1988. Structuralism, hermeneutics, and the Gospel of Mark. Perspectives in Religious Studies 10, 61-70.

Heyneke, F 1963. Korrespondensie: Dr A S Geyser preek in Nederlandssprekende Gemeente. Die Hervormer, Desember 1963, bl 24. (Jr $54 \mathrm{nr}$ 9.)

Jeremias, J 1968. The eucharistic words of Jesus. Philadelphia: Fortress Press. 1969. Jerusalem in the time of Jesus. Philadelphia: Fortress Press.

Klosinski, L E 1988. The meals in Mark. Ann Arbor: University Microfilms International.

Küng, H 1971. The church. 6th edition. London: Search Press.

Leach, E 1976. Culture and communication: The logic by which symbols are connected. Cambridge: Cambridge University Press.

Malina, B J 1986. Christian origins and cultural anthropology: Practical models for biblical interpretation. Atlanta: John Knox.

McVann, M 1988. The passion in Mark: Transformation ritual. BTB 18/3, 96-101.

— 1991a. Rituals as status transformation in Luke-Acts: The case of Jesus the prophet, in Neyrey 1991a:333-360.

1991b. Baptism, miracles, and boundary jumping in Mark. BTB 21/4, 151157. 
Naude, J P 1960. Korrespondensie: Prof A S Geyser propageer veelrassige gehore vir ons eredienste. Die Hervormer, Augustus 196o, bl 18. (Jr $51 \mathrm{nr} 5$. )

Neusner, J 1979. Map without territory: Mishnah's system of sacrifices and sanctuary. HR 19:103-127.

Neyrey, J H (ed) 1991a. The social world of Luke-Acts: Models for interpretation. Massachusetts: Peabody.

- 1991b. Ceremonies in Luke-Acts: The case of meals and table-fellowship, in Neyrey 1991a:361-387.

Neyrey, J H 1991c. The symbolic universe of Luke-Acts: 'They turn the world upside down', in Neyrey 1991a:271-304.

Oberholzer, J P 1993. Die teologiese eie-aardigheid van die Nederduitsch Hervormde Kerk: Vrae en nuanses. HTS 49/4, 870-886.

Pelser, G M M 1994. Enkele opmerkings oor die wese van die kerk. HTS 50/1 \& 2, 311-329.

Pervo, R I 1985. Wisdom and power: Petronius' Satyricon and the social world of early Christianity. ATR 67, 307-328.Sahlins, M D 1976. Culture and practical reason. Chicago: University of Chicago Press.

Pont, A D 1990. Ongepubliseerde herinneringe. KITAL-biblioteek, Nederduitsch Hervormde Kerk van Afrika.

- 1994a. Kerk en belydenis. Die Hervormer, 1 Oktober 1994, bl 5.

- 1994b. Kerk en belydenis (2). Die Hervormer, 15 Oktober 1994, bl 5.

Sahlins, M D 1976. Culture and practical reason. Chicago: University of Chicago Press.

Schillebeeckx, E 1987. Jesus in our Western culture: Mysticism, ethics and politics. London: SCM Press.

Tumer, V 1967. The forest of symbols: Aspects of Ndembu ritual. Ithaca: Cornell University Press.

1969. The ritual process: Structure and anti-structure. Ithaca: Cornell University Press.

Van Aarde, A G 1991. Hoe praat ons oor/van God? Teologies idiome in die prediking. Voordrag gelewer tydens Hervormde Teologiese Vereniging, 26 Junie 1991.

Van der Westhuizen, H G 1990. Volkskerk as normale kerkbeskouing, in Botha 1989:48-85.

- 1995. Korrekte kontekstualisering van die kerk. Die Hervormer, 15 April 1995 , bl 8.

Van Eck, E 1993. Galilee and Jerusalem in Mark's story of Jesus: A narratological and social scientific interpretation. DD dissertation, University of Pretoria. 
Van Eck, E 1994a. Memorandum: Konsep Kerorde en Ordinansies. Ongepubliseerde memorandum voorgelê tydens die buitengewone ringsvergadering van die Ring van Noordelike Pretoria, Januarie 1994.

_ 1994b. Kerk en belydenis: 'n Weerwoord. Die Hervormer, 1 Desember.1994, bl 4,8 .

1995. J H J A Greyvenstein en A S Geyser se teologiese denke oor die volkskerkgedagte. HTS 51/3, 825-850.

Van Staden, P 1991. Compassion - the essence of life: A social-scientific study of the religious symbolic universe reflected in the ideology/theology of Luke. Pretoria: University of Pretoria. (HTS Suppl 4.)

- 1994a. Mag 'slegs blankes!' hier aanbid? HTS 50/3, 713-729.

Van Staden, P 1994b. Woordverkondiging: 'n Universeelgerigte aksie. HTS 50/4, 1041-1069.

Van Wyk, D J C 1991. Kerk en volk. HTS 47/3, 768-782.

— 1994a. Redaksioneel: Kerk en teologie: Gesprek moet wyer en dieper. Die Hervormer, 15 Januarie 1994, bl 4.

1994b. Redaksioneel: Verskuiwings in ons teologie. Die Hervormer, $15 \mathrm{Mei}$ 1994, bl 4.

Van Wyk, I W C 1994. Nog steeds geslote eredienste? Deel 1. HTS 50/3, 755-779.

Van Zyl, F J 1989. Volkskerk en vrye kerk, in Botha 1989:86-98. 